\title{
The Axiological Principles as Foundation for Developing Sciences in Minangkabau Culture
}

\author{
Misnal Munir ${ }^{1}$, Rizal Mustansyir ${ }^{2}$, Moses Glorino Rumambo Pandin ${ }^{3}$ \\ $\underline{\text { misnalmunir@ugm.ac.id }}$, $\underline{\text { mustansyir@ugm.ac.id }}$, $\underline{\text { moses.glorino.r.p@mail.ugm.ac.id }{ }^{3}}$ \}
}

Universitas Gadjah Mada, Faculty of Philosophy, Jl. Bulak Sumur, Yogy akarta, Indonesia ${ }^{1,2,3}$

\begin{abstract}
The aim the study is to describe the axiological principles for developing sciences in Minangkabau culture. The research findings discovered that the values principles of Minangkabau culture can be applied to develop principle of sciences in Indonesian perspective. Based on theories of values, the research conduct qualitative method, especially hermeneutic approach in generating findings. The results revealed that the source of Minangkabau culture values is the Koran, the Minangkabau community places the intellectual as the determinant of value based on four categories type of mind referred to the value of good and evil. In the new Minangkabau culture, the values principle can be applied to several branches of sciences with the strategy of developing the sciences such as in Literature, Law, Politics, Psychology, Sociology, and Economics.
\end{abstract}

Keywords: Minangkabau culture, values, sciences.

\section{Introduction}

Although value is a new theme in philosophy, the emergence of axiology as a branch of philosophy of value around the second half of the nineteenth century (Risieri, F., 2001: 1), but the discussion of the question of value has been done by philosophers since ancient Greece such as Plato about beauty, kindness, and justice. There is quite a lot of agreement among philosophers on this value issue concerning the importance of human roles for understanding value. But there are also many things that still in debates such as: the is sue about the dominant in determining the value of good or bad, whether the subject or object. Frondizi and Archie Bahm, two expert on value issues, suggests that the notion of the nature of values is very complicated, as it involves the fact that many different types of values exist and that more chaos about value is caused by wrong ideas. (Bahm, 1984: 51). Therefore, to avoid misunderstanding about this value problem, the researcher will trace comprehension of value comprehensively, not by giving definition, but rather emphasize on illustration and description.

The value according to Frondizi's thought is the quality of the value-bearer as it is: the beauty of a painting. There are three categories of quality, namely primary, secondary, and tertiary qualities. Primary quality is the basic quality without existence of the object, for instance: length, weight. Secondary quality is a quality that can be captured senses such as: color, taste, smell. Tertiary quality is a quality that is not real, not independent, is parasitic, and is polar and hierarchical. A value is said to be independent, means that value is not free, because it must be attached to something. We will not be able to find the value of beauty, if it is not attached to an object such as a beautiful painting. The value is said to be parasitic, means it is always inherent on another object, without any other object the value will not exist. The value 
is said to be polarity means always raises the judgments of the polarizing such as: good or evil, beautiful or bad, right or wrong. The value is said to be hierarchical meaning is very possible the emergence of value gap in accordance with the evaluation of a person. For example: there is good, better, better still, and so on. (Risieri, F., 2001: 7-14).

\section{The Function of Values}

The role of values in human life is irrefutable, means both individually and socially, humans need value for the sustainability of their existence. Frondizi even asserts that the fundamental issue of axiology is not only emerging in the scientific world, but also in the everyday world. (Frondizi, 2001: 16). When there is a difference of opinion about something (e.g., an assessment of the delicious kind of cuisine by 3 culinary connois seurs), then that's when a fundamental problem of axiology arises. Here goes the Latin proverb that says: de gustibus non disputandum (a taste is not arguable). It is always possible to have an opinion on values that differ from one another, even though they all agree that the issue of value is just as important.

The human interest of value is beneficial to man. There are several benefits of human value that can be detailed as follows: First, value can help humans to discover the most intrinsic meaning of life, that is, for what man lives in this world. Without having a handle of value, human beings are no different from other living beings. The value of giving birth to various implications of norms, rules that make human life in the community become meaningful. Without value human is nothing, he does not exist, and the human aspect is questionable. Second, a value can help human beings find standardization. Because the differences that arise in the issue of value is very possible for conflict between individuals and groups. For instance: the value of nationality helps solve conflicts between tribes or regions by putting nationalis $m$ as a standard in living together in a country. Third, values can make people commit and responsible for their speech and actions. For freedom which is always required of every individual can grow into wild and endanger other individuals. Therefore freedom must always be faced with responsibility. Fourth, value can help people to answer the problems of life that develop along with the development of the era. For example, the problem of the value of life that is disturbed by the emergence of Mobile need to look for a way out, so that gave birth to the spirit of tolerance, tolerance among others. Fifth, value can help a community to develop and develop customs that are useful for the way of life of the community. For case in point: the value contained in Tambo Minangkabau culture. These value benefits will be explored further in this study.

\section{The Principle Values in Minangkabau Culture}

It has been pointed out that among the categories of values based on human life, there are two categories of human life value, namely personal values and cultural values. Personal values are related to the individual's beliefs about what he considers good or bad. While the cultural value is the value contained in a community, as a form of shared belief and adhered to. The relationship between the two values is cooperative, interpretative, fluctuating. First; said to be cooperative means that one can work with his community to adhere to the cultural values in which he lives. Someone who is difficult or not cooperative with his community will be excluded, is olated, and entrusted by his group. Second; said to be interpretative means one can reinterpret the cultural values according to the level of intelligence that he has. Example; an economist has a different interpretation with a politician about the same cultural value. Third; 
said to be fluctuating, meaning that cultural values can experience development or silting, depending on external factors that affect. Example: the entry of mobile technology to change the concept of hos pitality that was originally conceived as a form of visits to parties sometimes, be sufficient by sending Short Message System.

\subsection{The Source of Values}

The source of value in Minangkabau culture is the Koran, it is found in various Minangkabau customs, adat basandi syarak, syarak basandi kitabullah (al-Quran). This Minangkabau culture is the rule of life in society as a guideline for the life of Minangkabau society created by his ancestors, namely Datiak Perpatieh Nan Sabatang and Datuak Katumanggungan (Rajo Panghulu, 1994: 13) The teachings in Minangkabau culture that distinguish sharply between humans and animals are in the behavior and deeds, based on the virtuous doctrine and the noble moral of his fellow human beings and his natural environment.

The Minangkabau tradition regulates that the human life from the small to the bigger and bigger. The customary rules of conduct of small actions such as: how to sit, how to walk, the way to talk, the way to eat and drink, how to see, how to call parents, how to call younger, children, or respect others. Customary rules about great things such as arranging relationships among human beings in the life of society and nation. This rule is affirmed by the proverb that put forward the principle of harmony, the sayings: "nan elok di awak ka tuju dek urang, nan kuriak iyolah kundi, nan merah iyolah sago, nan baiak iyolah budi, nan indah iyolah baso" (when we think it is good, it also good according to others, the stripes is kundi, the red is saga, the good is mind, the beautiful is language). (Rajo Panghulu, 1994: 14-15).

The Minangkabau society puts reasons as a value determiner, a reason is an absolute tool in determining value criteria. Intellectual in Minangkabau language is also called ,aka“. It contains the understanding of all that can be done by human that comes from the reason. A logic, creativity, trickery, thought, and others are mentioned in an aka term. (Navis, 1986: 97). Human beings must have and use their reason whatever, positive or negative. Archie Bahm calls it the term intelligence as an important factor for understanding, interpreting and actualizing value problems. Furthermore, A.A. Navis (1986: 97-98) says in the Minangkabau community the intellect called aka contains two meanings; that is a meaningful reason (think), and also means the root (tree). Therefore, it is often use of the word sense that also associated with the root form, such as:

a. The wise (clever) is referred to as a person who has long aka, who can always solve problems faced and also think far ahead.

b. Clever people are called as people who have many aka, who always can solve problems faced with good results.

c. A sly person is called a person who has aka babalik (twisted sense), who always uses his mind to deceive or deceive people.

d. The fool is called a person who has short aka (singkek aka).

Discussion of the intellect is more a creative ethical teaching for the interes ts of the environment and personal interests, both in making judgments and in using reason rightly according to the Minangkabau culture philosophy that they inherited. Since human capabilities in using reas on are not the same, they divide the measure of reason into four categories. (a) Aka sajangka (a short mind), that is the measure of the intellect of one who always feels himself more intelligent than others; (b) Aka duo Janka (sense of two span), that is the size of the intellect of one who always feels himself as intelligent with others; (c) Aka tigojangka (sense 
of three span), that is the size of the intellect of people who always feel themselves less clever than others; and (d) Akabajangka-janka (resourceful mind), that is the measure of the mind of people who always feel themselves need to learn to everyone, both to the smart, and to the less clever.

$A k a$ (mind) becomes decisive in various decisions, for the Minangkabau community, the person of reason can be seen from both the inner and inner aspects. The sign of a reasonable person is as follows: (1) Can be seen in the birth, he is quiet, patient, humble, and like to do good; (2) Can be seen in mind, he wants to learn, likes to give, diligent worship, and dare to tell the truth. But on the contrary there are people who just do not have the ability to use the mind well, so called people who lose reason. Four things that cause people to lose sense, namely: (a) it is fear of reality and challenges; (b) it is shame to see the weakness of yourself; (c) it is Evil, looking at everything from a bad angle; (d) it is Fool, unable to use mind.

Based on the inherited teachings, for the Minangkabau community, personal sense must be elaborated or applied in social life. So it can be useful for (1) To keep the mind, to always be noble; (2) To maintain oneself, to keep them safe; (3) To keep the people, to always be prosperous; and (4) To keep the treasure, to always give grace.

The benefit of reason for Minangkabau society in relation to the principle of value is to make consideration for the six virtues, namely: (a) to weigh the light weight, to always be fair; (b) Weighing high low, to always be polite; (c) Considering profit loss, to always be lucky; (d) Considering behavior, to always be liked; (e) Considering des picable noble, to always be honest; and (f) Considering the effort, to always be virtuous.

The potential of reason as the power of judgment to make decisions of action in the philos ophy of values is called "moral judgment". Reason is something that God delivers in the human heart that has a signal to the brain that can distinguish the easy and the difficult. The easy thing is evil, and the difficult is the way of goodness. However, not all the way of reason and the human mind can be used in life. Because there is reas on for the good, and there is also reason for evil. Archie Bahm in value theory calls this the problem of good and evil as two things that are always contradictory non-contradictory. So the ultimate goal of humankind is to maximize the good and minimize the ugliness, because both things are just as important in the theory of values and are always present in human life.

The mind in Minangkabau culture is divided into five levels (Rajo Penghulu, 1994: 85)

a) Aka sambarang aka: it is the intellect that spreads down and down, which creeps left and right, the intellect which it wishes to gain, the mind that does not distinguish between good and bad.

b) Aka manjala: it is the intellect that spreads down and down, creeping left and right, is a reflection of greedy, jealous and envy.

c) Aka takumpa: it is a mind that sleeps and dies, hides and then goes away, sleeps a lot more than awakens, a long-minded reason.

d) Aka tawaka: it is a careful mind, using faith and obedience, patient and sincere, waiting for the destiny of God.

e) Aka nan sabana aka: it is the mind that always considers merit and harm, weighing the beginning and ending, distinguishing the halal and haram (the prohibited things to eat), the circumcision and the obligatory, knowing Allah and the Messenger (Prophet Muhammad SAW), who always remember life will die, which can distinguish the low and the high, the just in punishing.

The mind of human beings in Minangkabau culture is aka nan sabana aka. Since this reasons that can lead people toward goodness, it is this mind that can give a good leadership to society. 
This mind is also in accordance with the teachings of adat basandi syarak, syarak basandi kitabullah. (Culture based on Koran).

\subsection{The Equal Value Principle}

The Minangkabau people give high attention to the harmonious teachings of balance with the term "raso jo pareso" (a taste through investigation). A. A. Navis (1986: 73) said everything must be weighed with the same size of feeling and with equal examination. The size of raso or feeling is pain and pleasure. For the pain is known the expression of law "piciak jangek, sakik deak awak, sakik dek urang". That is, if we feel pain when pinched, then others will experience the same thing if we treated as well. Therefore, the hidden advice behind this phrase is not to harm others in any way and form, both soul and body, as long as we also feel pain when we get the same treatment. In terms of pleasure the phrase is "lamak dek awak, katuju de dek urang" it means, happy for us, happy also for others. It means that every pleasure we do should be liked by others. Here the private interests must be linked to social interests, so that the balance of humanity appears to exist as individual creatures with human beings as social beings.

The size of the pareso (investigation) will use the value of the groove and proper (alua jo pauik), it means to check a problem according to the custom, still consider it with a sense of appropriateness or check it with a measure of conscience. However, if it is in a state of coercion or emergency, when the value of raso jo pareso is not possible, one may adopt other methods that does not follow the usual grooves (according to custom). This method is expressed by pameo: Awak mandapek urang indak kailangan (when we get something, others will not lose it). It means we can do something we want, but others do not feel harmed. This pameo can indeed be used for various circumstances, whose meaning is the same as tolerance, but is more passive than raso jo pareso.

The Minangkabau community is an intact collection with all human diversity of different interests and abilities and with all its good and evil that will be able to create possibilities, but it will not be to eliminate each other. This is possible, because they embrace the developed natural philosophy of being a teacher. Peggy Reeves Sanday translates it into English with the phrase Nature is our teacher (2002: 13). As natureas a teachers, whose elements are mutually distinct roles and attributes, but it mingles in an equally important position in the universe. Each individual has a role according to his physicalcondition and intellectual ability as said in proverb [appendix A].

\section{The Developing Principle Values for Sciences}

Science evolves on the basis of human planning, especially scientists, with a variety of considerations and in line with the needs of man himself. Science begins with a human curiosity (curiosity) over the phenomena that exist around him or about himself. At first the desire to know was hampered by the myths that flourished in society. The most obvious example seen in Greek history shows how mythology overwhelmed Greek civilization for a dozen centuries. Then came the philosophers who opposed the mythology with the power of reason, so that gave birth to branching science such as: logic, as tronomy, arithmetic, and grammar.

The myth is successfully embedded in the human mind, because of the limitations of the human mind itself to provide and obtain a plausible explanation. The myth instantly slips into the human mind without scientific procedure, it is more a cultural product that is crys talizing in the minds of people without a critical response. In the end myth can enlarge the distance between 
reality (reality) and science because it is inserted with an attitude of irrationality that is clearly contrary to the scientific spirit that reclining rationality.

One of the scientific missions is to undermine myths through scientific explanations that can quench the thirst of human curiosity. Although scientific explanations put forward in a period may not necessarily satisfy the scientific community at another period. But scientific explanation is a necessity in the scientific stage, because it demands a logical and argumentative logic flow that leads to scientific theory. A scientific theory is essentially a collection of statements, whether symbolic or not, that can accommodate the facts around them.

The history of human civilization shows various scientific products capable of leading humanity toward progress. Stephen F. Mason in his A History of Sciences (Mason, 1962: 11) explained that the roots of science can be traced back to the time before the advent of human civilization. This means the history of science moves along with human evolution. Stephen Mason continues in the same work that science has historical roots in two main sources, first the technical tradition in which practical experience and skills are acquired and developed from one generation to another; both spiritual traditions where human aspirations and ideas are circulated and supplemented. (Mason, 1962: 11).

If we look at the history of the development of science, then the technical and spiritual traditions as proposed by Mason was appearing clearly in the scientific world stage. That is, we cannot decide that the scientific products, whether it is imitation or any other technological things, presents in a certain period of time as separate from previous times. There is a journey of science history that rolls like a snowball that continues to accumulate, thus presenting scientific theory as it is today. The development of science in this world is a necessity as long as humans live in it, because the various internal demands of human curiosity as a civilized creature, and external needs in the growing community.

In line with internal and external demands for the development of science, the role of cultural values is an indispensable scientific dimension. As cultural values evolve in a community and crystallize into the form of custom, the cultivation of cultural values forms the space of human consciousness, which in turn affects behavior and decision making. This is where the interaction or contact between cultural values with scientific value. History of science shows that the emergence of science is always preceded by a tradition or spirit that developed in a community.

This tradition or spirit becomes the driving force and control of the development of science. Thus, the axiological principle contained in Minangkabau society can be used as a driver and control of the development of science in Indonesia. Several illustrations and examples presented in the following sections will show the role and contribution of Minangkabau cultural values to Literature, Law, Politics, Psychology, and Sociology.

\subsection{The Role of Minangkabau Culture Value for Literature}

One of the obvious roles and contributions in the history of literature in Indonesia is the emergence of great literature such as AbdulMuis with his work "Shackles", HAMKA with his worked "Di bawah Lindungan Ka'bah" (Under the Protection of Ka'bah), and A.A.Navis with his book titled: "Robohnya Surau Kami". The literary works show the dominance of Minangkabau culture thoughts and values, so that the wider community in Indonesia can recognize the Minangkabau culture tradition through these works. The Balai Pustaka and Pujangga Baru era shows the dominance of literature (including Minangkabau) in various curriculum of elementary to secondary education. Therefore, the planting of cultural values that reflect local Minangkabau wisdom can be done in educational institutions in Indonesia. The 
noble values reflected in Minangkabau culture is like the principle of harmony contained in saying: "nan elok di awak ka tuju dek urang, nan kuriak iyolah kundi, nan merah iyolah sago, nan baiak iyolah budi, nan indah iyolah baso”.

\subsection{The Role of Minangkabau Culture Value for Law}

The cultural value of Minangkabau plays a very big role in customary law, so it can make an important contribution to the development of positive law and le gislation in Indonesia. One of the famous phrases, „Adat basandi syara, syara' basandi Kitabullah“ implies that the customary law rules of the Minangkabau community stem from the values of culture and religion. The strong protection of women in Minangkabau shows that adat law strongly refers to the Qur'an which gives protection to women (Al-Quran, An-Nisaa ': 19). The protection of women's rights in Minangkabau such as the ownership of a traditional gadang house is an important contribution to the development of law in Indonesia. Fair means taking steps that are not one-sided, and sticking to the truth. Being fair like this, very difficult to do when dealing with dunsanak himself. It is because of proverbs that said "Adat dunsanak, dunsanak dipatahankan". Minangkabau custom teaches in the proverb [appendix B].

\subsection{The Role of Minangkabau Culture Value for Politics}

Political science is concerned with issues of power, leadership, and decision-making. Minangkabau people are political experts because they get a saying from their ancestors with the goal of achieving happiness together through deliberation and consensus. In Minangkabau nature though many kingdoms, but full of proverbs and leaders should do justice like in proverb [appendix C and D].

So it is clear that almost all sectors of life are supplemented with proverbs and when we dig back, then we believe the Minangkabau people had the superior values compare to other surrounding areas. The basic Minangkabau philosophy about life are consist of composition of society; community journey, and economy. The worldliness and the destiny to be perfectly arranged in a system of social intercourse whose purpose is to be the happiness of the Hereafter, the important thing that is related to the world are about: a personal life, social life, and economy. The subject of decision making by consensus is expressed in the proverb [appendix E]:

\subsection{The Role of Minangkabau Culture Value for Psychology}

Psychology studies the psychological aspects of the human being that can affect one's behavior. The role of Minangkabau cultural values is reflected in the following proverb [appendix F]. The core phrase mentioned in the proverb that one should develop a culture of shame in personality in order to influence the psychological aspect in associating with others.

\subsection{The Role of Minangkabau Culture Value for Sociology Science}

The science of sociology studies human interaction in social life. The role of Minangkabau cultural values is reflected in the expression in community life, the Minangkabau uphold the value of egalitarian or togetherness. This value expresses them with the phrase "Duduak samo randah, tagak samo tinggi". In activities related to the public interest their communal and collective nature is very prominent. They highly uphold deliberation and consensus. The result of a consensus is the highest authority. 
The highest authority according to the Minangkabau people is abstract, i.e. nan bana (truth). The truth must be sought through deliberations that are guided by the plot, proper and possible. The use of common sense is required by Minangkabau people and highly valued human beings who use reason. The values brought by Islam put the Muslim mind first, and Is lam complements the use of reason with the guidance of faith. With the source of human values perfected with the value derived in revelation, further perfecting the Minangkabau community life.

According to the custom the view of one's self towards the other should be the same even though one has different functions and roles. Although different are needed and need each other so there is togetherness. It is said in the customary mamangan culture: "Nan buto pahambuih lasuang, nan pakak palapeh badie, nan lumpuah paunyi rumah, nan kuek pambaok baban, nan binguang kadisuruah-suruah, nan cadiak lawan barundiang”. Only the function and role of someone is different from others, but as human each person should be appreciated for the mutual content of each other, to respect each other in order to have harmony in the as sociation, customs laid down "nan tuo dihormati, samo gadang baok bakawan, nan ketek disayangi". The arrival of the Islamic concept of the concept of views towards others again reinforced.

The egalitarian value which the Minangkabau upholds encourages them to have high self-esteem. Collective values based on matrilineal social structures that emphasize widespread responsibility such as from the people to the Nagari community, cause a person to feel ashamed if they do not succeed in contributing something to their relatives and ninja society. This interaction between self-esteem and social demands has caused the Minangkabau people to always be dynamic. Human feelings are subtle and very sensitive. If offended a little, then he will be hurt. Good intercourse, is a social that can keep the feelings of others. If it gets hurt, it can bring disaster. Therefore, culture teaches that we always be careful in association, whether in speech, behavior or deed not to offend the feelings of others. The tolerance of one of the recommended properties of culture as show warning in proverb [appendix G].

\subsection{The Role of Minangkabau Culture Value for Economics}

Economics learns about human endeavor to pursue prosperity in their lives. The proverbs that take advantage of the economy are so many even more prominent once the way business and mutual cooperation which eventually became national property [appendix $\mathrm{H}$ ].

In Minangkabau culture there are two types of treasures, namely the high heirlooms and the lower heirlooms or also called iron and silver buckets of silver whose arrangements are regulated arranged by the leaders (penghulu or Ninik Mamak), treasure by the father. In earning a living whether as traders, workers, peasants and others there is also a guidance in the ancestors Minangkabau ancestors in proverb [appendix I]. Even an advice is also given to the wander looking for the needs of the abdomen is not filled, the back is not covered with the saying [appendix J]. This means that if a young person goes to wander, you should find a leader who can teach you how to have good business.

The ancestors of Minang people, before management science flourished in the country since the 1950s ago, have long believed that "mature planning" is one of the most important elements for the realization of a job that it believes to be true: [appendix K]

\section{Conclusion}

The value system in Minangkabau culture is loaded with axiological principles. The source of value in Minangkabau culture is the Koran. It is found in various Minangkabau culture 
or customs, adat basandi syarak, syarak basandi kitabullah (Koran). The axiological principles in the new Minangkabau culture can be applied to several branches of science such as: literature, law, politics, psychology, sociology, and economics.

The development strategy of these sciences that is sourced from local wisdom value is needed so that society is not merely an object in science application, but can participate as a dialogue partner for scientists. Application of Minangkabau culture values into several branches of science. It needs to be elaborate further, so the application of axiological principles from local wisdom to the level of science, es pecially into the development strategy of science in Indonesia can be done on an ongoing foundation. This means that science development strategy in Indonesia in the future must be able to incorporate local wisdom values as control and characteristic of science.

The strategy of science development in Indonesian perspective should be able to give consideration of value in two areas, first pre-science that is before systematically structured science local wisdom role to be considered, so that science developed later become familiar in society. Second, the operational area of science, meaning local wisdom play an active role in the process of science, not just as legitimacy and value justification, but play an active role in every scientific action decision with all its consequences.

\section{References}

[1] Amir, M.S.: Adat Minangkabau Pola dan Tujuan Hidup Orang Minang. Mutiara sumber Widya, Jakarta (2003)

[2] Bahm, A. J.: Axiology: The Science of Values, Albuquerque, New Mexico (1984)

[3] Djamaris, E.: Tambo Minangkabau; Suntingan teks disertai Analisis Struktur, Balai Pustaka, Jakarta (1984)

[4] Risieri, F.: What is Value?, Cuk Ananta Wijaya (translation), Pustaka Pelajar, Yogy akarta (2001)

[5] Nasruddin, H.: Profil Propinsi Sumatera Barat, Yay asan Bhakti Wawasan Nusantara, Jakarta (1992)

[6] Hunnex, M. D.: Chronological and Thematic Charts of Philosophies and Philosophers, Chandler Publishing Company, Michigan (1986)

[7] Hugh, L.: Is Science Value Free?, Routledge, London (1999)

[8] Longino, H. E.: "Values and Objectivity", in Philosophy of Science: The Central Issues, Edited by: Martin Curd and J.A.Cover, W.W.Norton and Company, New York (1998)

[9] Ma'arif, A. S.: "Gagasan Demokrasi dalam Perspektif Buday a Minangkabau”, in Muhammad Najib et. al. (eds), Demokrasi dalam Perspektif Buday a Nusantara, LKPSM, Yogy akarta (1996)

[10] Mahmoed, St., and Pangulu, A. M. R.: Himpunan Tambo Minangkabau dan Bukti Sejarah, Pustaka Indonesia, Medan (1987)

[11] Mason, S.. F.: A History of the Sciences, Collier Books, New York (1962)

[12] Nasroen, M.: Dasar Falsafat Adat Minagkabau, Penerbit Pasaman, Jakarta (1957)

[13] Navis, A.A.: Alam Terkembang Jadi Guru; Adat dan Kabuday aan Minangkabau, Grafiti Pers, Jakarta (1986)

[14] Rajo Penghulu, I. H. Dt.: Pokok-Pokok Pengetahuan Adat Alam Minangkabau, Remaja Rosda Karya, Bandung (1994)

[15] Rajo Penghulu, I. H. Dt.: Pegangan Penghulu, Bundo Kanduang dan Pidato Pasambahan Adat Minangkabau, Remaja Rosda Karya, Bandung (1994)

[16] Sanday, P. R.: Women at the Center: Life in a Modern Matriarchy, Cornel University (2002)

[17] Majo Indo, A.B., Dt.: Kato Pusako (2004) 